\title{
Koripallotähti vai tuholainen? Rottien tulkitseminen kulttuurisissa konteksteissa
}

\author{
ELLA VIHELMAA \\ ella.vihelmaa@gmail.com
}

\begin{abstract}
ABSTRAKTI
Semiotiikan näkökulmasta eläinkäsityksemme rakentuvat monenlaisissa lajinsisäisissä ja lajienvälisissä käännösprosesseissa. Ihminen kääntää kielenulkoista eläimyyttään kielellisiksi merkeiksi puhuessaan hormonaalisesta tilastaan tai hammassärystään, sykkeestään tai väsymyksestään, mutta yhtä lailla ihmiskielelle käännetään toislajisten eläinten tuottamia merkkejä. Lajienvälisiä suhteitamme määrittääkin ratkaisevasti se, mitä toislajisia merkkejä milloinkin käännämme ja miten. Lajienvälisessä käännöstoiminnassa ihmislajin valtakausi tuntuu siinä, kuinka ympäristömme tulkitsijoina keskitymme ihmisten tuottamiin merkkeihin. Silloin kun toislajisten merkkejä vaivaudutaan kääntämään, tulkintaa ohjaavat inmisten tilannekohtaiset tarkoitusperät. Tätä kuvastaa se, kuinka yhteismitattomin tavoin rottia tulkitaan eri yhteyksissä - tiedekeskuksen koripallomestareista viemärin lainsuojattomiin.
\end{abstract}

AVAINSANAT: rotat; konteksti; kuuluisat eläimet; rottasota; kääntäminen; endosemiotiikka 


\section{Johdanto}

Kääntäjä tekee työtään erilaisten eläindiskurssien ristiaallokossa; tätä ei voi olla huomaamatta, kun seuraa kotvan kääntäjäverkostossa käytyä keskustelua. Yksi vertailee suomalaista ja brittiläistä lihapiirakkaa, toinen painiskelee rodeosanaston kanssa, kolmas kääntää kieleltä toiselle eläinkoeraportteja. Konteksti palautuu kollegoiden mieleen, kun kysyjä aloittaa viestinsä huolta herättävällä lauseella: "Rottia rääkätään edelleen..." Rottien tilanne nousee puheeksi, ennen kuin päästään käsiksi itse asiaan, koejärjestelyn tekniseen yksityiskohtaan. Kulttuurisessa eläintutkijassa keskustelu herättää kysymyksen, onko tekstissä käsiteltyjen rottien kohtalo lopulta kumminkaan pelkkä sivuseikka. Voiko kääntäjä kokea tilivelvollisuutta paitsi toimeksiantajalleen myös kuolevien rottien laumalle? Tulisiko kääntäjän sulkea korvansa toislajisten lähteiden ultraääniltä, jotka koettelevat kieliopin rajoja?

Kääntäjältä odotetaan usein empatiaa, herkkyyttä, huomaavaisuutta ja kuuntelun taitoa (ks. Bourjea 1986; Chesterman 2001), eikä sikäli ole ihme, että patenttitekstin kääntäjä sivumennen tulee suomentaneeksi paitsi kokeiden kemiallisia yksityiskohtia myös kliinisen kielen alle verhoutunutta tuskaa. Tästä herää kysymys, kuinka pitkälle kääntämisen rajoja voi venyttää: pystymmekö tulkitsemaan paitsi lajitoveriemme sanoja myös toislajisten ja -lahkoisten eläinten merkkejä? Biosemiotiikan näkökulmasta kaikki elämä muodostuu merkkiprosesseista (Sebeok 2001), ja itsessään tiedostamattomat fysiologiset tapahtumat johtavat toisinaan mentaalisiin tulkintoihin. Esimerkkinä tästä toimivat tiedekeskus Heurekan julkaisemat blogitekstit, joissa reflektoidaan rottien polveutumista, itsesuojeluvaistoa ja silmän toimintaa. Matka elämästä tekstiksi ei kuitenkaan ole suoraviivainen; kun rottien biologisista toiminnoista puhutaan, niihin kietoutuu monenlaisia inhimillisiä merkityksiä.

Käännösprosesseille on tunnusomaista merkkien kytkeytyminen uusiin merkitysyhteyksiin ja semioottisten kiintopisteiden vaihtuminen. Rottien parissa toimivien ihmisten kirjoitukset ilmentävät kontekstin vaikutusta siihen, kuinka rottalähtöisiä merkkejä käännetään kulttuurisiksi ilmiöiksi. Tilanteesta riippuen rotat voivat näyttäytyä vaikeasti hallittavina joukkoina tai yksilöinä, jotka elävät yleensä vankeudessa. Koerotat saavat osakseen yksilöllistä huomiota, mutta heidän julkista tulkitsemistaan leimaa kliinisen tieteellinen kieli (ks. Kahn 2001). Lemmikkirotan ja ihmisen välille sitä vastoin voi muodostua intiimi suhde, josta myös julkisissa keskusteluissa puhutaan affektiivisesti. Tieteellisen ja viihteellisen käytön välimaastoon sijoittuvat Heurekan koripallorotat, joihin kytkeytyvä työ toisaalta pyrkii edesauttamaan lemmikkirottien hyvinvointia (KPR 26.4.2014 ym.). Torjuntafirma Rentokilin tulkitsemista rotista sitä vastoin 
on ihmisille pelkkää harmia, ja heitä tulkitaan sen mukaisesti. Jos rotat maallikossa herättävätkin ristiriitaisia tunteita, Rentokil pyrkii vakuuttamaan tämän tuhoamisen tarpeellisuudesta. Heurekan ja Rentokilin rottakäännösten vertailu auttaa huomaamaan, kuinka yhteismitattomia tulkintoja samanlajiset eläimet saavat erilaisissa kulttuurisissa konteksteissa.

\section{Aineistot ja analyyttinen viitekehys}

Artikkelin puitteissa en voi ottaa huomioon kulttuuristen rottatekstien koko kirjoa. Siksi keskityn kahteen verkkoaineistoon, jotka ilmentävät aikamme rottasuhteiden yhteismitattomuutta. Yhtäällä rottia pyritään tuhoamaan; toisaalla rotista tulee eräänlaisia tiedeyhteisön jäseniä.

Rentokil Initial Oy on Isossa-Britanniassa 1925 perustettu yhtiö, joka on toiminut Suomessa vuodesta 1932 lähtien. Rentokil Initial koostuu kolmesta osastosta, joista Rentokil tarjoaa asiakkailleen tuholaistorjuntapalveluita, Initial hygieniapalveluita ja Ambius viherpalveluita. Rentokilin suomenkielisen verkkosivuston (Rentokil n. d.) ilmeisenä tarkoituksena on tuholaistorjunnan markkinointi, mihin liittyy asenteiden muokkaamista rottakielteisemmiksi. Artikkelissa käsiteltävät esimerkit edustavat Rentokilille tunnusomaista viestintätyyliä ja kattavat merkittävän osan sivuston rottatulkinnoista. Rentokilia koskevat huomiot eivät kumminkaan ole yleistettävissä torjunta-alaan kokonaisuudessaan; osa toimijoista puhuu rotista kunnioittavammin sanakääntein kuin Rentokil, jonka suomenkieliset tekstit lienevät osittain käännöksiä englanninkielisistä. Tältä kannalta Rentokilin tulkinnat ilmentävät kielteisten rottakäsitysten rakennusaineksia sekä kääntäjän roolia kulttuurisen rottasuhteen muotoutumisessa.

Toisena tutkimusaineistona toimivat tiedekeskus Heurekan blogitekstit, joissa eläinkouluttajat tulkitsevat Heurekan koripallonäytöksissä esiintyvien rottien elämää. Koripallorottien voi katsoa edustavan lahkonsa eliittiä. Yhteistyö jyrsijöiden kanssa vaatii heidän tekemistensä ja olemistensa huolellista tulkitsemista, ja siinä sivussa rotista tulee eläinkuuluisuuksia (ks. Malamud 2007), joiden elämää käännetään yhä uudelleen opastusdiskurssiksi ja sosiaalisen median julkaisuiksi. Aineisto on peräisin kahdesta eri blogista, joista ensimmäiseen (Koripallorotat) viittaan nimellä KPR, toiseen (Rottakoripallo) nimellä RKP. 27.10.2010-8.12.2016 julkaistu KPR käsittää 118 lyhyehköä kirjoitusta, 17.11.2016-20.2.2018 ilmestynyt RKP 28 kirjoitusta.

Tiedekeskuksen tehtäviin kuuluu fysiologisen tutkimustiedon popularisointi, ja näin blogitekstit havainnollistavat rottatulkintojen biosemioottisia lähteitä. Samalla Heurekan ja Rentokilin tulkinnat auttavat selvittämään, millaisia ilmenemismuotoja 
lajienvälinen kääntäminen saa tieteellis-viihteellisessä ja torjuntahenkisessä kontekstissa. Yhteismitattomien rottakäännösten vertailussa käytän työvälineenä lajienvälisen kääntämisen kuutta merkitystä, jotka olen esitellyt tutkimuksessani Kielen kääntöpuolella (Vihelmaa 2018). Tässä artikkelissa määrittelen merkitykset vain lyhyesti.

Kolme ensimmäistä merkitystä koskevat kääntämistä merkkiprosessin anonyymien osatekijöiden työstämisenä. Interformaalisen kääntämisen lähtökohtana on merkin aistittava muoto, intermediaalisessa kääntämisessä semioottinen energia virtaa kanavasta tai olomuodosta toiseen, kun taas intersysteemisessä kääntämisessä merkkijärjestelmiä suhteutetaan toisiinsa. ${ }^{1}$ Loput kolme merkitystä jäsentävät kääntämisen osaksi viestinnän osapuolten välistä suhdetta. Intersubjektiivisessa merkityksessä on kyse kääntämisestä lähtösubjektin tunnetilan tulkitsemisena. Interaktantiaalisen merkityksen valossa kääntäminen hahmottuu lähtötoimijan intressien semioottiseksi prosessoimiseksi. Intermondiaalisen kääntämisen tavoitteena taas on ymmärtää, mitä jonkun toisen henkilökohtaisessa tai ryhmäkohtaisessa todellisuudessa on tekeillä. Kuuden merkityksen yhteisvaikutuksesta muodostuvia kulttuurisia rottia on usein vaikea hahmottaa saman eläinlajin edustajiksi.

Jos Heureka tarjoaa mahdollisuuden rottasuhteemme rajojen koetteluun, niin tuholaisten torjunnalle omistautunut Rentokil sitä vastoin kuittaa rotat yleisluontoisilla stigmoilla. Sue Donaldson ja Will Kymlicka (2011) pitävät kielteistä leimaamista yhtenä perusongelmana suhteessamme liminaalisiin eläimiin, jotka elävät kesyn ja villin rajamaastossa tai saapuvat kutsumattomina vieraina kaupunkeihimme. Eläinkoeteksteistä poiketen Rentokilin tulkinnat eivät ole tyyliltään kliinisiä, vaan rotat näyttäytyvät sinnikkäinä vihollisina, joiden tuhoamista käännöstoiminnan toivotaan helpottavan. Rentokilin lähestymistapaa voisi luonnehtia rottasodan käsitteellä, joten Heurekan ja Rentokilin käännöksiä vertailemalla rottatulkintojen yhteismitattomuus nousee oivallisesti esiin. Kumpikin taho myös vaikuttaa vahvasti kulttuurisiin rottasuhteisiimme: 1990-luvulla käynnistyneissä Heurekan rottakoripalloesityksissä käy noin 54000 katsojaa vuosittain (RKP 1.6.2017; Heureka n. d.), ja Rentokilin edustajat päätyvät usein haastateltaviksi esimerkiksi rottia koskeviin lehtijuttuihin. Ennen siirtymistä analyysiin onkin syytä pohtia lyhyesti rottien tulkitsemiseen liittyviä eläinpoliittisia haasteita.

1 Semioottisen energian virralla tarkoitan merkin elämän jatkumista vaikkapa valokuvien kaltaisten tallenteiden tai mediavälitteisen julkisuuden muodossa. Intermediaaliseen kääntämiseen ei välttämättä kuulu semanttista tulkintaa saati viestin dekoodausta ja uudelleen koodausta; kyse on pikemminkin huomion kiinnittämisestä, josta Roman Jakobson (1960) puhuu viestinnän faattisena funktiona. 


\section{Rajatapausten tulkitseminen}

Ajatus toislajisten tulkitsemisen ylittämättömistä vaikeuksista verrattuna kieltenväliseen kääntämiseen perustuu osittain spesistisiin ennakko-oletuksiin eli yhden lajin nostamiseen muiden yläpuolelle. Lähtökohtana on maailma, jossa eläinkunnan jäsenet jaetaan kahteen leiriin, 'ihmisiin' ja 'eläimiin'. Kaksinapaiset jäsennykset eivät ole ontologisesti järin lujalla pohjalla - jakolinjasta riippuen kaltaiseni ihminen voisi päätyä samaan leiriin uusmaalaisen ketun, kasveja syövän kirahvin tai naaraspuolisen lampaan kanssa. Kulttuurisessa eläintutkimuksessa puhutaan nykyisin paljon erojen risteävyydestä; näin halutaan tuoda esiin, että identiteetti sijaitsee aina useamman tekijän leikkauskohdassa ja että yksilö kuuluu samaan aikaan useampaan ryhmään (ks. esim. Deckha 2008). Toisaalta ryhmät ovat monin tavoin sidoksissa toisiinsa, ja tätä kautta oma marginaalinen tai alisteinen asema suhteessa johonkin voisi analogisesti auttaa ymmärtämään toislajisten tilanteita.

Käännöstutkijoiden näkemyksistä riippumatta toislajisten eläinten elämää joka tapauksessa kielennetään keskusteluiksi, somejulkaisuiksi, tietokirjallisuudeksi, tieteellisiksi teksteiksi ja sanataiteeksi. Jos puheenaihe tulkitaan merkeiksi ja kielentäminen kääntämiseksi, eläimistä puhumista alkaa ohjata translatologinen eetos. 'Eläin' ei ole pelkkä tulkitsijan mielivallalle altis objekti vaan tuottaa merkkejä, joiden elämä jatkuu käännöksissä. ${ }^{2}$ On esitetty, että käännösparadigma eli semioottisten ilmiöiden tarkastelu käännöksinä auttaa ymmärtämään sisäisiä jännitteitä tai tekemään oikeutta lähtötekstin yksilölliselle ainutkertaisuudelle (ks. Bachmann-Medick 2009; Kull ja Torop 2003; West 2002). Ihmisyhteisössä yhteisiä asioita hoidetaan usein kielen välityksellä, ja sikäli toislajisten puolesta puhuminen on monilajisen yhteisön toiminnassa jokseenkin yhtä keskeistä kuin kääntäjien ja tulkkien työ kansainvälisessä politiikassa.

Susan Oyama (2006) esittää, että puheenvuoron antaminen ihmisiä ympäröiville asioille tuo ne taustalta huomion keskipisteeseen; puhe ruokkii esimerkiksi toislajisia naapureitamme koskevia ajatuksia, keskusteluja ja tekoja heidän hyväkseen. Ajatus äänen antamisesta niin sanotun ympäristön osille käy oivallisesti yhteen kääntäjille tunnusomaisen rajojen ylittämisen, tekstin hengitykseen eläytymisen, toisen nahkoihin liukumisen kanssa (ks. Bourjea 1986). Samaan arvokokonaisuuteen sujahtavat luontevasti

2 Nähdäkseni monilla ihmisillä on taipumuksena käyttää hyväkseen sitä, minkä he eivät kuule puhuvan puolestaan, ja projisoida mykkään materiaan omia halujaan. Hiljaisilla ihmisillä on omakohtaista kokemusta tulkinnallisesta mielivallasta, mutta vastaavasti on esitetty, että esimerkiksi ongitun kalan äänettömyys ja ilmeettömyys estävät näkemästä kärsimystä (ks. Willamo 2005: 141). 
Oyaman (2006) edellyttämät puheen vivahteikkuus ja taipuisuus sekä oman osuuden tunnustaminen maailman puhuttamisessa.

Käännösparadigman soveltaminen totuttua laajemmalle mahdollistaa myös ammatissa toimivan kääntäjän eheytymisen. Usein kääntäjässä on kaikupohjaa sellaisillekin äänille, jotka lähtötekstissä on tukahdutettu, jolloin koetun tilivelvollisuuden ja toimeksiannon välinen ristiriita voi johtaa kaksijakoiseen toimintamalliin. Jos empaatikko kääntääkin leipätyönään eläinkoetekstejä toimeksiantajalle, hän ei saata olla ohimennen suomentamatta koerottien oletettuja tuntoja kollegoille, jotka tarjoavat vertaistukea. Ammattikääntäjän kaksoiselämä voi olla psyykkisesti kuluttavaa, mikä puoltaa osaltaan oikeutta kääntää myös alakynteen jääneitä ääniä. Vuonna 2004 toteutettu kyselytutkimus suomalaisten kääntäjien ympäristöetiikasta osoitti, että osassa kääntäjistä aatteellisesti vieraiden tekstien kääntäminen synnyttää kyynisyyttä, inhoa, vieraantumista tai masennusta (Vihelmaa 2009). Ristiriitoja syntyy, kun toimeksiantajan intressit menevät ristiin oman eettisen tajun kanssa. Kieltenvälistä ammattikääntämistä ei järjestetä yksinomaan liike-elämän ehdoilla, vaan esimerkiksi potilaille ja rikoksesta epäillyille pyritään tarjoamaan maksuton tulkki. Suurta osaa käännöstoiminnasta ohjaavat kuitenkin taloudelliset näkökohdat, ja toislajisten eläinten puolesta puhuminen jää usein vapaaehtoisten harteille.

Lajienväliset käännöstarpeet riippuvat osittain siitä, millainen suhde ihmisillä on tulkittaviin eläimiin. Donaldson ja Kymlicka (2011) ehdottavat, että yhteiskuntamme alkaisivat suhtautua villieläimiin suvereeneina yhteisöinä, joilla on oikeus omaan alueeseensa ja joiden edustajia ei saa vahingoittaa. Domestikoituja eläimiä tulisi Donaldsonin ja Kymlickan mukaan pitää kansalaisina, jotka saavat osallistua omaa elämäänsä koskevaan päätöksentekoon. Suvereenien villieläinyhteisöjen ja domestikoitujen kansalaisten rinnalla Donaldson ja Kymlicka erottavat omaksi ryhmäkseen liminaaliset eläimet eli rajatapaukset. Rajatapaukset ovat sopeutuneet elämään ihmisten keskuudessa, vaikka ihmiset eivät nimenomaisesti kasvattaisi heitä. Heihin lukeutuvat rotat, pulut, toreilla parveilevat lokit ja cityhuuhkajat, joiden asemaa Donaldsonin ja Kymlickan mukaan voi verrata paperittomiin siirtolaisiin. Vaikka välillämme ei ole vahvoja sosiaalisia siteitä, emme filosofien mielestä saisi vainota cityeläimiä. Hyväksyvässä rinnakkainelossa rotat ja pulut voivat omalla tavallaan rikastuttaa arkeamme. (Donaldson ja Kymlicka 2011.)

Suvereenin eläinyhteisön tulkki voisi työssään pyrkiä tietoisuuden kasvattamiseen ja diplomatiaan, domestikoitujen äänitorvi toislajisten vaikutusmahdollisuuksien kasvattamiseen, rajatapausten puolestapuhuja ennakkoluulojen hälventämiseen, suvaitsevuuteen ja tyydyttäviin kompromisseihin. Yksistään laji ei kuitenkaan ratkaise eläimen asemaa yhteiskunnassamme. Varsinkin rotan kaltaisella sopeutuvaisella olen- 
nolla mahdollisuuksien kirjo on loputon, mikä käy havainnollisesti ilmi Marianna Kurton 32:sta rotasta kertovasta runosta. Joku "kasvattaa syöpää laboratorion / kirkkaudessa", joku on "prinsessa / sävyltään cinnamon pearl", joku "sekoittaa tunteita kuin kauha puuroa", joku "lepää / lautasella", joku "juoksee ojanreunaa / lähiössä", joku "rakentaa museota / hevostallin rakenteisiin", joku "pelaa koripalloa" (Kurtto 2015, 83-87). Koeja lemmikkirottien elämä on yleensä melko kontrolloitua, vaikka he kuuluvat samaan lajiin kuin kaatopaikalla asuvat isorotat; näin myös kansalaisuuden ihanne voi jäädä tavoittamatta.

Yhteiskunnan eri sektoreilla saman lajin jäseniä tulkitaan eri tarkoitusperissä, mikä on osittain perusteltua. Oikeudenmukaisen kohtelun varmistamiseksi kääntäjän kannattaa kuitenkin kiinnittää huomiota myös taksonin edustajia yhdistäviin semioottisiin prosesseihin. ${ }^{3}$ Seuraavaksi tarkastelenkin kenen hyvänsä rotan tulkitsemisen fysiologisia lähtökohtia.

\section{Elämä semioottisina prosesseina}

Jos tahdomme tarkastella kääntämisenä erilaisten eläinten tuottamien merkkien tulkitsemista, kielikeskeisestä ajattelusta on siirryttävä ei-kielellisten merkkien merkityksen täyspainoiseen tunnustamiseen. Fysiosemiotiikan edustajat näkevät semioottisia piirteitä jopa elämän syntyä edeltäneessä maailmankaikkeuden järjestäytymisessä (ks. Deely 2001); biosemiotiikka puolestaan tarkoittaa elollisen luonnon tutkimista merkkiprosesseina. ${ }^{4}$ Esimerkiksi Kalevi Kull (2010) katsoo jokaisen solun olevan semioottinen kokonaisuus, joka ottaa vastaan informaatiota ja muuntaa toimintaansa suhteessa johonkin kolmanteen tekijään. Elämää ei redusoida mekaanisiksi syiksi ja seurauksiksi, vaan huomio kiinnittyy sen autopoieettiseen, itseään uusintavaan toimintaan (ks. Brier 2010). Biosemioottisesta näkökulmasta ihmisillä ja muilla eläimillä on paljon yhteistä merkkien tuottajina ja käyttäjinä. Tätä ilmentää osaltaan sekin, kuinka ihmisen fysiologisia prosesseja eläinkokeissa mallinnetaan toislajisten eläinten kautta.

3 Taksonin edustajia yhdistävillä semioottisilla prosesseilla en viittaa rottien keskinäiseen viestintään vaan siihen, mikä on heille yhteistä. Esimerkiksi hermosto on samankaltainen riippumatta siitä, päätyykö rotta lemmikiksi vai koe-eläimeksi; silti eläimiä kohdellaan aivan eri tavoin kategoriasta riippuen (ks. Serpell 1996). Ylimalkaisimmillaan rottaa saatetaan kauhistella evoluution saatossa kehkeytyneenä lajina, mutta yksittäisten rottien kohtelua säätelee se, kuinka ihmisten tuottamat luokitukset risteytyvät biologisiin eroihin.

4 Kuten edellä esitin, elollisen luonnon samastaminen merkkiprosesseihin on Sebeokin käsitteellinen keksintö; biosemiotiikassa on myös muita suuntauksia, joissa merkkiprosessi voidaan määritellä kapeammin, ja toisaalta fysiosemiootikot ulottavat semiosiksen elottomaankin luontoon. 
Yksi mahdollisuus biosemiotiikan kentän jäsentämiseen on endosemioottisen erottaminen eksosemioottisesta. Endosemioottisissa prosesseissa on kyse eliön sisäisistä semioottisista tapahtumista, kun taas eksosemiotiikka tarkoittaa eliön ja ympäristön semioottista vuorovaikutusta. Bio- ja eläinsemiotiikan uranuurtajan Thomas Sebeokin (2001) mukaan niin ihmisten kuin muidenkin eläinten elämä nojautuu neljään perustavanlaatuiseen endosemioottiseen koodiin. Näitä ovat geneettinen koodi, immunologinen koodi, metabolinen koodi ja neurologinen koodi. Neljän koodin toiminta on lähtökohtaisesti riippumatonta ihmisen toiminnasta, eikä valtaosa siitä milloinkaan kielenny tai nouse tietoisuuteen. Sinfoniakonsertit ja avaruuslennot sitä vastoin rakentuvat biosemioottisten prosessien varaan. Kuten Risto Willamo $(2005,173)$ huomauttaa, "vaatimattominkaan taideteos tai alkeellisinkaan tieteellinen havainto" ei ole mahdollinen, ellei "biokemiallisten pelisääntöjen mukaan toimiva ruoansulatusjärjestelmä" irrota energiaa aivojen ja lihasten käyttöön. Vastaavasti Harold Fromm (1996, 38-39) luonnehtii ihmismieltä hauraaksi paatiksi, joka keikkuu helposti saastuvalla verivirralla.

Biosemioottisen tutkimuksen kohteena ovat biologiset merkkiprosessit itsessään; niukemmalle huomiolle on jäänyt endosemioottisten ja kielellisten prosessien välinen vuorovaikutus, johon dualismin välttämiseksi on syytä kiinnittää huomiota. Ihmiskielet ovat kehittyneet vuorovaikutuksessa lajille tunnusomaisen fysiologian kanssa ja soveltuvat kenties luontevimmin pystyasennossa liikkuvan päiväeläimen kokemusten mallintamiseen. Silti ihmisenkään keholliset tapahtumat eivät kielenny automaattisesti, vaan oma keho voi olla kielenkäyttäjälle jossain määrin arvoituksellinen semioottinen objekti. Välittömien kehollisten tuntemusten ohessa ulkokohtaiset havainnot, fysiologiset taustatiedot sekä erilaiset apuvälineet, kuten kuumemittarit, raskaustestit ja röntgenkuvat, tuottavat inmiskehosta merkkejä, joita tulkitsemme kielellisesti. Tietoisuuteen ja kielellisyyteen suuntautuvat rönsyt eivät katkaise endosemioottista prosessia sen enempää kuin Kalevalan kääntäminen vietnamiksi estää lukemasta sitä suomen kielellä.

Kun fysiologisia tapahtumia kielennetään, endosemioottisista prosesseista liu'utaan kohti yksilöiden välistä, eksosemioottista vuorovaikutusta. Ihmiset kielentävät jatkuvasti omia endosemioottisia kuulumisiaan ja lajitovereiden endosemioottisia tilanteita. Ihmisen kasvun, vanhenemisen, tautien, ruoansulatuksen ja neurokemiallisen tilan antroposemioottinen prosessointi voidaan tulkita myös kääntämiseksi. Ei-kielellisten ilmiöiden kielellinen kuvailu on keskeistä muun muassa kuurosokeille tulkkauksessa ja kuvailutulkkauksessa. Translatologisessa kirjallisuudessa kääntämisenä on tarkasteltu myös tarpeiden, tunteiden, kivun, aistiärsykkeiden ja aivoperäisten kokemusten kielentämistä (ks. Steiner 1975, 283-284; Jackson 2003; Segal 2003; Thiong'o 2009). 
Laajemmin kääntäminen on ymmärretty todellisuuden kielentämiseksi, nimeämiseksi, tietämiseksi tai selittämiseksi (ks. Benjamin 1977; Lefevere 1977, 62; Berman 1984; Derrida 1990).

Käännösprosessissa on aina monia vaiheita, ja usein kääntäminen on kokemusvälitteistä. Kääntäjä saattaa puhua verkkokalvoilleen osuneista fotoneista häikäisynä tai lajitoverin käyttäytymisessä havaitsemistaan oksitosiinin vaikutuksista äidinrakkautena. Bio- ja fysiosemioottisessa katsannossa käännösprosessit kuitenkin ylittävät yksilöllisen kokemuksen rajat; siksi käännöstutkija Michael Cronin (2017) kehottaa kääntäjää kääntämään katseen ihmiskokemuksesta maapallon syvään historiaan (deep history). Syvähistoriallisessa perspektiivissä ihmislaji näyttäytyy historiallisena ilmiönä (ks. Chakrabarty 2009), jonka syntymää edelsi vuosimiljardien mittainen tapahtuminen. Eduardo Kohnin (2013) tavoin voidaan väittää, että eliöiden kehityslinjoissa tapahtuu ajattelua tai ympäristöä koskevaa oppimista, joka ylittää sukupolvien rajat ja luo verkostoa etäisempienkin sukulaisten välille. Näin lajirajat madaltuvat, ja osallisuutemme suuriin biologisiin kehityskulkuihin piirtyy esiin.

Jos endosemiotiikan ja kielen välinen raja on ylitettävissä ihmislajin sisällä, herää kysymys, miksi toislajisten eläinten endosemioottista elämää tai siihen perustuvia eksosemioottisia viestejä ei voisi tai saisi kääntää kielelle. Onko isorotan DNA:sta suurempi hyppy kieleen kuin nykyihmisen perimästä? Pitäisikö rotan ja paiseruttobakteerin välistä kamppailua tulkita toisenlaisin sanakääntein kuin tartunnan saaneen ihmisen fysiologiaa? Tapahtuuko riisinjyvälle rotan vatsassa vallan muuta kuin ihmisen sisuksissa? Jos rotan hermoston toiminta perustuu samankaltaisiin aistinreseptoreihin ja välittäääaineisiin kuin ihmisten, voimmeko soveltaa häneen samoja havainto- ja tunnesanoja kuin ihmiseen? Jotkut teoreetikot katsovat, että kielellä ei saisi ollenkaan kajota toislajiseen. Tiedekeskus Heurekan blogiteksteissä kielellisiä tulkintoja kuitenkin saavat niin rottien geenit, immuunijärjestelmä, aineenvaihdunta kuin hermostokin.

\section{Rotan endosemiotiikan suomentaminen}

Käännösprosesseissa päädytään harvoin yksi yhteen -vastaavuuksiin merkkien välillä. Usein käännös perustuu useampiin lähtömerkkeihin, ja toisaalta yksittäinen merkki voi poikia koko joukon käännöksiä, kun sitä tulkitaan eri koodeilla ja konteksteissa. Käännösprosessit ovat myös monitasoisia; samaan aikaan kun geenit, vasta-aineet, entsyymit ja välittäjäaineet elävät omaa elämäänsä, reflektoiva ihminen voi kääntää biologiset tapahtumat tietoisiksi merkityksiksi. Endosemioottisista koodeista geenit näyttäytyvät elämän kielenä, joka mahdollisti semiosiksen jo kauan ennen ihmiskielen syntyä 
(Sebeok 1991). Toisaalta DNA-sekvenssit kääntyvät luontevasti myös erilaisiksi kulttuurisiksi koodeiksi. Kun eliöitä ryhmitellään polveutumissuhteiden perusteella, perimä kääntyy fylogeneettisiksi kaavioiksi ja nämä sukulaisuutta tulkitseviksi sanoiksi. Tämä on ilmeistä myös Heurekan rottatulkinnoissa:

\begin{abstract}
Rattus-suvusta löytyvät kaikki rotan läheisimmät sukulaiset, jos eivät löydy, jokin on luokittelussa pielessä. Kukaan ei tarkkaan tiedä kuinka paljon Rattus-lajeja on, kymmenittäin joka tapauksessa (tällä hetkellä 66). [...] Rotiksi kutsutaan myös monia muita jyrsijöitä, jotka eivät välttämättä ole läheistä sukua Rattuksille. Nisäkkäiden uudet nimiehdotukset ovat osittain parantaneet nimeämisen logiikkaa, osittain sekoittaneet sitä entisestään. (KPR 11.11.2012)
\end{abstract}

Dna-vertailuista on ollut iso apu siihen, että vähän paremmin on opittu tunnistamaan, että mikä rotta on mitäkin lajia. Dna-vertailut ovat paljastaneet, että lajinmääritykset pelkän ulkonäön perusteella menevät parhailta asiantuntijoiltakin usein pieleen. (KPR 4.6.2013)

Perimään perustuvaa nimeämistä on myös kritisoitu (ks. Dupré 2002), mutta Heurekan tulkinnoissa DNA näyttäytyy todenmukaisen luokittelun lähteenä. Vaikka fylogeneettinen luokittelu ei kaikissa tapauksissa vastaisi totunnaista käytäntöä tai intuitiota, sen etuna voi pitää juuri rottalähtöisyyttä; vastapainona kulttuurisille vaikutteille käsitteiden rajoja muokkaa rottien omaehtoinen esihistoria. Toisaalta inhimillinen perspektiivi risteytyy geneettisen koodin lahjomattomuuteen kaikissa taksoneille annetuissa nimissä. Isorotta tuskin kokee olevansa jättiläinen ihmisen rinnalla, mutta ihmiset korostavat jyrsijän kokoa paitsi omakohtaisiin kohtaamisiin liittyvissä anekdooteissa myös suomenkielisessä lajinimessä.

Sebeok (1991) näki immuunijärjestelmässä endosemioottisen koodin, joka pitää yllä eliön identiteettiä tehden rajan sisäpuolen ja ulkopuolen välille. Elimistö tunnistaa kehoon ujuttautuneen antigeenin ja vastaa uhkaan kasvattamalla valkosolujen tuotantoa. Joskus valkosolu muuttuu muistisoluksi, joka tunnistaa aiemmin kohtaamansa taudinaiheuttajan ja valmistaa tämän tuhoavaa vasta-ainetta (Campbell et al. 2008). Näin ollen immuunijärjestelmän toiminnassa on ilmeinen semioottinen ulottuvuus. Niin ihmisillä kuin rotillakin puolustusjärjestelmän vajeet voivat johtaa yksilön heikkenemiseen tai elämän päättymiseen. Kumpiakin on menehtynyt sankoin joukoin esimerkiksi ruttoepidemioissa. Heurekan rottakäännöksessä tulkitaan sanoilla rotan immuunijärjestelmän horjumista ja siitä johtuvaa identiteetin häviämistä: 
Toksoplasma on pikkuruinen yksisoluinen eliö, mutta se osaa tehdä täsmäiskun aivoihin: rotan synnynnäinen kissanpelko katoaa ja, kaiken huippuna, rotta voi suorastaan "rakastua" kissanpissan hajuun, suhtautua siihen samoin kuin urosrotta kiimassa olevaan naaraaseen. Normaali kissa ei osoita vastarakkautta, vaan syö rotan. (KPR 5.1.2013)

Laajasti ymmärrettynä immunologisessa koodissa ei ole kyse yksinomaan mikrobeilta puolustautumisesta vaan muustakin itsesuojelusta. Toksoplasmoosiin sairastuneessa rotassa mikrobille altistuminen kytkeytyy häkellyttävällä tavalla itsesuojeluvaiston romahtamiseen. Sairastunut rotta ei ole enää oma itsensä, ja mahdollisesti toksoplasmoosi voi johtaa jonkinasteiseen persoonallisuuden muuttumiseen myös ihmisessä (Webster et al. 2006). Rotan tai ihmisen kukoistus vaihtuu Toxoplasma gondiin voittokulkuun, jota toisaalta sävyttävät rottaan liitetyt myönteiset tunteet - kissanpissan hajuun rakastuminen. Näin tulkinta saa kaikupohjaa lukijan omista irrationaalisista kokemuksista. Samastumaan kutsuu myös tulkinta kesäflunssaan sairastuneesta Hilpasta, jonka vastustuskykyyn etsitään lisäpotkua valkosipuliuutteesta ja puolukkajauheesta (KPR 14.7.2013). Toisaalta rotan tautia pyritään normaalista flunssasta poiketen nujertamaan myös antibioottikuurilla.

Kolmanneksi endosemioottiseksi koodiksi Sebeok (1991) nimesi aineenvaihdunnan. Eläinkunnassa metabolinen koodi perustuu kemiallisia reaktioita nopeuttavan entsyymitoiminnan, reaktioiden lopputuotteiden pitoisuuksien sekä entsyymitoimintaa säätelevien tekijöiden vuorovaikutukseen (Campbell et al. 2008). Semioottisesta näkökulmasta esimerkiksi lopputuotteen pitoisuutta voi pitää merkkinä, jota elimistö tulkitsee edelleen. Yksinkertaisimmillaan tulkitsijana toimii entsyymi itse: se tunnistaa ympäristönsä molekyyleista juuri sellaisen, joka soveltuu sen substraatiksi, muuttaa muotoaan substraattiin sitoutumisen seurauksena ja usein myös lakkaa toimimasta, kun lopputuotetta on riittävästi (Campbell et al. 2008). Lisäksi aineenvaihduntaan vaikuttavat hormonaaliset merkit, jotka symboloivat muun muassa verensokeria (Sebeok 1991; Campbell et al. 2008).

Jyrsijät ovat kädellisille läheisempää sukua kuin esimerkiksi märehtivät sorkkaeläimet, joiden aineenvaihdunnan avaintekijöihin kuuluu symbioosi selluloosaa hajottavien esitumallisten kanssa (Campbell et al. 2008). Usein ihmisen metabolisia prosesseja tutkitaan rottien avulla, mikä on auttanut tunnistamaan lajirajat ylittäviä hyvinvoinnin lähtökohtia:

Miten ehkäistä kasvainten tuloa? Terveellinen ravinto auttaa tässäkin. Olen kuullut, että soijapavut saattaisivat suojata nisäkasvaimilta. Eläimet 
elävät pidempään tutkimusten mukaan, jos joutuvat ajoittain olemaan niukemmalla ravinnolla, eli liikasyöttämistä tulisi välttää. Samoin pitäisi välttää suolaisten, sokeristen ja muiden epäterveellisten herkkupalojen syöttämistä, roskaruoka ei ole hyväksi rotillekaan! Useimmiten rottien ruokinnassa pääsee helpolla, jos muistaa mikä on terveellistä ihmiselle, on usein myös terveellistä rotalle, kaikkiruokaisia eläimiä kun olemme kummatkin. (KPR 23.8.2012)

Heurekan tulkinta nojautuu vahvasti lahkojenväliseen yhteenkuuluvuuteen, mitä osaltaan korostaa monikon ensimmäinen persoona. Terveysdiskurssista tutut käsitteet, kuten terveellinen ravinto, ehkäiseminen, suojaaminen ja roskaruoka, näyttävät yhtä lailla relevanteilta rottien kuin ihmistenkin kohdalla. Osaltaan tähän vaikuttaa se, että rottien oletetaan elävän ihmisyhteisössä, missä suolaisia ja sokerisia herkkupaloja on saatavilla. Autonomisesta ihmistoimijasta poiketen rottien aineenvaihdunnan toiminnallisena kehyksenä ei kuitenkaan ole ruokailijan harjoittama itsekuri, vaan rotat näyttäytyvät liikasyöttämisen potentiaalisina vastaanottajina. Herkkupalan lähettäjän ja vastaanottajan välinen työnjako kytkeytyy kysymykseen vastuusta, jolloin itsessään endosemioottiset tapahtumat saavat moraalisen ulottuvuuden.

Geenien, immuunijärjestelmän ja aineenvaihdunnan ohessa eläimille tunnusomainen endosemioottinen koodi on hermosto (Sebeok 1991). Hermosolujen toimintaa kuvataan usein viestien kuljettamiseksi, mikä tähdentää niiden semioottista luonnetta. Hermosolun sisällä tai vaikkapa näköreseptorissa viesti välittyy sähköisesti, kun taas useimmissa synapseissa ja makureseptorin kaltaisissa aistisoluissa kanava on kemiallinen (Campbell et al. 2008). Heurekan blogiteksteistä selviää, että rottien ja ihmisten keskushermostoissa esiintyy samoja välittäjäaineita, kuten dopamiinia ja opioideja (RKP 17.4.2017). Lisäksi blogiteksteissä käännetään kielelle rotan neurologista koodia tulkitsemalla hermoston rakennetta ja aistimuksia:

Rotan verkkokalvon aistisoluista peräti 99 prosenttia ovat sauvasoluja. Ihmisellä vastaava luku on reilu viisi prosenttia, sillä ihmisen silmän verkkokalvolla on noin 120 miljoonaa tappisolua ja noin 7 miljoonaa sauvasolua. Rotta pystyy meitä ihmisiä paljon paremmin erottamaan eri harmaan sävyjä, ja on herkempi pienillekin muutoksille valon intensiteetissä. (RKP 20.10.2017)

Vertailukohtana rotan näköreseptoreille toimivat omat verkkokalvomme, mikä kotouttaa tulkintaa - toisaalta juuri vertaileminen auttaa astumaan ulos ihmishermoston itsestäänselvyyksistä. Semioottisia äänenpainoja sisältyy myös tulkintaan sitä, mitä solu- 
jakauma merkitsee rotan havaintomaailmalle; samassa hengessä teksti tulkitsee rotan näkökenttää, syvyysnäköä ja värinäköä (RKP 20.10.2017). Jatkopäätelmiä sävyttävät epistemologinen varovaisuus ja ihmiskielelle kääntymättömien ulottuvuuksien tunnustaminen, mikä ei kuitenkaan estä kuvittelemasta rotan neurologiseen koodiin pohjautuvaa kokemusta.

Kuten Heurekan teksteistä voidaan huomata, biosemioottisista prosesseista versovat kielelliset käännökset ovat monivaiheisen prosessin tulosta. Läheskään aina endosemioottiset merkit eivät ole sellaisinaan havaittavissa, jolloin kääntäjän täytyy kiinnittää huomionsa esimerkiksi rotan käyttäytymiseen, mikroskoopista avautuvaan näkymään tai DNA-sekvensserin tuottamaan raporttiin. Käännöksillä ei myöskään ole yksittäisiä lähteitä; läsnäolevan rotan elämää saatetaan tulkita toisaalta saadun tiedon valossa. Hybridisessä välittyneisyydessäänkin käännökset kertovat endosemioottisesta maailmasta, joka on lähtökohdiltaan ihmisestä riippumaton.

Endosemioottisten koodien ohessa Heurekan rottakäännöksissä tulkitaan rottien eksosemioottisia viestejä, kuten ilmeitä, eleitä ja ilmaisuvoimaisia äänï. Pienen rotan kerrotaan näyttävän alistumiseleitä isommilleen, ja kouluttajan niskaan pissaaminen tulkitaan ystävälliseksi rakkauden osoitukseksi (KPR 23.12.2012; KPR 22.11.2011). Usein eksosemioottisia merkkejä tulkitaan endosemioottisen koodin suomassa ristivalossa, jolloin vaikkapa motorinen suuntautuminen ja neurologiset merkit vahvistavat toisiaan:

\footnotetext{
Rotanpoikaset myös hakeutuvat mielellään sellaisiin paikkoihin, joissa ovat aikaisemmin painineet toisen rotan kanssa. Tämä voi antaa osviittaa siitä, että rotat kokevat mielihyvää painiessaan toisen ikätoverin kanssa. Niiden aivokemia tukee myös tätä näkemystä. Rotilla erittyy nimittäin tavallista enemmän dopamiinia juuri ennen leikin alkua ja leikin aikana elimistön omia opioideja. Sekä dopamiini että opiodit liittyvät mielihyvän tunteeseen. (RKP 17.4.2017)
}

Katsaus Heurekan blogitekstien tulkintoihin osoittaa, että rottien endosemiotiikkaa on luontevaa kielentää siinä missä ihmiskehonkin tapahtumia. Tämä luo perustaa myös rottien tunteiden, intressien ja näkökulmien tulkitsemiselle. Käytännössä kulttuuriset rottatulkinnat eivät kuitenkaan ammenna yksinomaan endosemioottisesta ymmärryksestä ja viestinnällisistä merkeistä; kaikupohjaa haetaan ihmisten omista kokemuksista ja vaihtelevista konteksteista (vrt. Verschueren 2007). Kieltenvälisestä kääntämisestä tuttuun tapaan rotan viestiin voidaan kytkeä esimerkiksi inhimillisiä tunteita tai teoreettisia periaatteita, jotka mukauttavat sitä tietyn yleisön semioottisiin tottumuksiin 
(vrt. Lefevere 2004). Tulkinnallisen kontekstin merkitys korostuu entisestään, kun fysiologisten prosessien kielentäminen vaihtuu rottien kohtaamiseen koripallorottina tai tuholaisina. Kuinka Heurekan rottatulkinnat poikkeavat Rentokilin vastaavista, jos tekstejä vertaillaan kuuden merkityksen puitteissa?

\section{Saastaisuudesta sirkutukseen - rottien interformaalinen tulkitseminen}

Interformaalisen kääntämisen piiriin lukeutuvat yhtäältä yleisluontoiset tulkinnat lähtöeläimen olemuksesta. Rentokil (n. d.) luonnehtii rottia hyvin ylimalkaisesti saastaisiksi: "Miksi rotista on päästävä eroon? Rotat ovat saastaisia [...]." Ajatus rottien saastaisuudesta on länsimaissa vanhaa perua ja kytkeytyy kiinteästi heidän liminaaliseen, luokituksia uhmaavaan asemaansa (vrt. Douglas 2000). Saastaisuuden varaan on rakennettu myös monia erojen risteävyyden kannalta mielenkiintoisia käsiterakenteita; Arnold Arluke ja Clinton Sanders (1996) ovat selvittäneet, miten natsi-Saksassa juutalaiset samastettiin rottiin. Toisaalta interformaalinen ulottuvuus painottuu, kun lähtöeläimen aistittavia erityispiirteitä esitetään kielellisesti. Rentokililla yksityiskohtaiset interformaaliset kuvaukset eivät koske rotan ulkonäköä, liikkeitä tai ääniä vaan rotasta syntyviä tahroja ja jätöksiä. Rentokilin (n. d.) mukaan rotan ruumis on niin rasvainen ja likainen, että siitä jää tummia jälkiä sinne, missä rotta liikkuu. Myös rotan ulosteita kuvataan varsin yksityiskohtaisesti: ne ovat tummanruskeita, kartiomaisia, värttinän muotoisia, noin 9-14 millimetriä pitkiä (Rentokil n. d.).

Jos torjutut rotat jäävät vaille yksilöllisiä erityispiirteitä tai ominaislaatua, niin Heurekan rotista sitä vastoin tuodaan esiin viehättäviä tuntomerkkejä. Yhdellä on "kirjava kuviointi naamassa" (RKP 4.12.2017), toisen selässä kulkee ruskea raita "päästä häntään saakka" (KPR 13.1.2014). Usein ulkonäön yksityiskohdat saavat kulttuurisia merkityksiä; esimerkiksi yksivärinen turkki on Heurekan rotalle peliasu, joka määrää, mihin koripallojoukkueeseen hän sijoittuu (KPR 10.1.2011). Heurekassa tulkitaan melko monivivahteisesti paitsi sitä, miltä rotat näyttävät, myös sitä, miltä he kuulostavat. Äänet kääntyvät onomatopoeettisiksi sanoiksi kimeä, viserrys ja sirkutus ja synesteettiseksi metaforaksi korkea (RKP 17.4.2017; RKP 8.5.2017). Kokonaisvaltaisia tulkintoja yksittäisistä rottapersoonista Heurekankaan teksteissä ei juuri esiinny; kuitenkin esimerkiksi Halla-rottaa luonnehditaan käsitteellä pikkuvipeltäjä (RKP 27.4.2017). Kaikkiaan Heurekan interformaaliset tulkinnat ovat monipuolisia verrattuina Rentokiliin, jonka teksteissä rottia edustaa metonyymisesti lika. 


\section{Maineen puhdistamisesta täyteen katsomoon - rottien intermediaalinen tulkitseminen}

Intermediaalisella kääntämisellä tarkoitan lähtöeläimen merkkien välittämistä uusiin viestintäkanaviin ja välitysprosesseja koskevaa reflektiota. Rentokililla (n. d.) intermediaalisen kääntämisen lähtökohtana on oletus, että ihmiset eivät halua olla missään tekemisissä rottien kanssa: "Mitä pikemmin pääset rotista eroon, sen parempi." Omissa ympyröissä rottien merkit on huomattava ennen muita ja rotat tuhottava, ennen kuin kukaan saa asiasta vihï - muuten maine on pilalla. Varsinkin liikeyrityksissä merkit tuholaisista saattavat "vahingoittaa merkki-imagoa ja yleistä mielipidettä", "vahingoittaa kovalla työllä ansaittua mainettasi" tai "vaarantaa koko maineesi". Onneksi rottaongelmasta huolestunut ihminen voi luottamuksellisesti soittaa Rentokilille, joka "puolustaa mainettasi tuholaisten viekkaudelta" (Rentokil n. d.).

Heurekassa tilanne on täysin päinvastainen. Siellä rotille on kysyntää, ja kasvattajien yhteydenotot ovat erittäin tervetulleita (KPR 16.1.2012). Rotat ovat "yksi Heurekan ikisuosikeista" (RKP 19.5.2017); jokaiseen koripallo-otteluun riittää yleisöä, ja "sesonkiaikoihin katsomo on revetä liitoksistaan kolmesti päivässä" (KPR 29.8.2012). Rottiin voi pitää yhteyttä myös etänä. Sen lisäksi, että Heurekan rottien kaikki koulutustuokiot dokumentoidaan videoiden ja kirjallisten päiväkirjojen avulla (KPR 28.3.2016 ym.), rottien kuulumisista viestitään tiiviisti yleisölle. Rottien tekemiset välittyvät blogeihin, Facebookiin, runoihin, iltapäivälehtiin, televisioon ja mainoksiin (KPR 3.2.2011; KPR 19.6.2011; KPR 5.9.2014; KPR 6.4.2016 ym.). Joskus rottien kuvaaminen on kuitenkin haasteellista heidän nopeiden liikkeidensä vuoksi: vikkelän kaverin kuvaaminen saattaa edellyttää päiväkausien yrittämistä (KPR 10.1. 2011). Kaikesta julkisuudesta huolimatta rotat myös säilyttävät tulkinnoissa tietyn salaperäisyyden: "Mysteeriksi jää mitä rottalassa tapahtuu öisin." (KPR 28.3.2016.)

\section{Itse tuholaisesta elekieleen - rottien intersysteeminen tulkitseminen}

Intersysteemisellä kääntämisellä tarkoitan sitä, kuinka kääntäjä pyrkii tunnistamaan lähtöeläimen merkkijärjestelmiä ja suhteuttamaan niitä inhimillisiin merkkijärjestelmiin. Rentokilin (n. d.) teksteissä puhutaan monenlaisista rottien merkeistä: jätöksistä, raapimisjäljistä, jalanjäljistä, juoksujäljistä, hankausmerkeistä, vaurioista, pesistä ja käytävistä. Kaikki nämä ovat kuitenkin saman ongelman merkkejä, jotka havaitaan mutta joita ei tulkita muuten kuin osoituksina tuholaisen läsnäolosta. Rentokil (n. d.) antaa ymmärtää, että öiseen aikaan olisi mahdollista havaita myös itse tuholainen, kun taas 
semioottisen ajattelutavan mukaan kanssakäyminen on aina merkkivälitteistä.

Heurekan rottien merkkejä sitä vastoin tulkitaan ilmaisuvoimaisina viesteinä ja vastauksina. Sosiaalisissa tilanteissa esiintyvä kehonkieli ilmentää rotan suhtautumista ihmisiin; esimerkiksi "matala asento ja hieman taakse suuntautuneet korvat kertovat, että Tildaa taisi hieman jännittää valokuvaajan läsnäolo" (KPR 25.11.2012). Kouluttajat seuraavat sivusta myös rottien keskinäistä viestintää. Poikanen vastaa aikuisen rotan rehentelyyn "heittäytymällä selälleen merkiksi alistumisesta" (KPR 18.6.2012). Talvirotalle vanhemmat rotat "viestittävät [...], että pelikentällä on turvallista olla" (KPR 20.9.2016).

Joskus Heurekan teksteissä pyritään suorastaan lukemaan rotan ajatuksia ja kääntämään niitä suomenkielisiksi lauseiksi. Hilppa-rotta "tuntuu ajattelevan, että 'eihän tämä näin yksinkertaista voi olla, että pudotan vain pallon koriin'" (KPR 2.5.2013). "Hyppäisikö tutkimaan lattiaa, pohtii Lempi." (KPR 2.11.2012.) Rottien ja ihmisten vuorovaikutusta myös reflektoidaan intersysteemisestä näkökulmasta: "kouluttajan tulee tarkkailla koulutettavan elekieltä" (KPR 1.9.2016). Valmennusfilosofiassa tähdennetään, että "koska emme voi kommunikoida valmennettavan kanssa samalla kielellä, on meidän valmentajien oltava yhdenmukaisia vaatimuksissamme" (KPR 14.9.2011). Avoimeksi jää mahdollisuus, että rotilla on oma kielensä, jota ihmiset eivät ymmärrä sen enempää kuin rotat meidän puheitamme.

Heurekan blogissa käydään myös paljon keskustelua uusien rotanpoikasten nimeämisestä. Rottien nimet ovat tietenkin ihmiskielisiä, mutta intersysteemisessä kääntämisessä ei yksinomaan suhteuteta ei-kielellisiä merkkejä kielellisiin vaan samalla rotat imaistaan mukaan muihin kulttuurisiin merkkijärjestelmiin. Vuoden 2018 poikasten nimillä kunnioitettiin satavuotiasta Suomea ja sen tiedenaisia (RKP 4.12.2017). Nimiehdokkaiksi valittiin ansioituneita suomalaisia tutkijoita, kuten Suomen ja Euroopan ensimmäinen eläinlääkäri Agnes Sjöberg, ensimmäinen suomalainen naistohtori Lydia Sesemann, lääketieteen ja kirurgian tohtori Karolina Eskelin ja Suomen ensimmäinen naisprofessori Alma Söderhjelm (RKP 4.12.2017). Sitten poikaset nimettiin eniten äänï saaneiden tiedenaisten kaimoiksi (RKP 14.12.2017). Tämän tyyppinen kotouttaminen antaa rotille kansallisuuden ja saa heidät tuntumaan yhä selvemmin meikäläisiltä.

\section{Onnellisuudesta ilon tunnistamiseen - rottien intersubjektiivinen tulkit- seminen}

Intersubjektiivisella kääntämisellä tarkoitan jonkun toisen subjektiivisten tilojen tulkitsemista. Rentokilin sivustolla rottien intersubjektiivinen tulkitseminen on niukkaa. Kun 
kyse on rottien torjumisesta jyrsijämyrkyillä, ensimmäisenä kysymyksenä luulisi olevan se, kuinka paljon kärsimystä myrkky tuottaa jyrsijälle. Suomessa tavallisimpiin jyrsijämyrkkyihin kuuluvat antikoagulantit (Tukes n. d.), jotka saavat rotan kuolemaan sisäisistä verenvuodoista aiheutuvaan verenvuotosokkiin (Watt et al. 2005). Valmisteesta riippuen jyrsijän odotetaan menehtyvän 4-10 päivän sisällä myrkyn syömisestä (Tukes n. d.). Vuonna 2014 antikoagulantteihin perustuvia jyrsijämyrkkyjä myytiin Suomessa 250000 kiloa, ja myös luonnonvaraiset eläimet altistuvat niille laajamittaisesti (Koivisto et al. 2016).

Rottia myrkytetään jopa luomutiloilla, joten yksityisen ihmisen on vaikea sanoutua irti torjuntakäytännöistä esimerkiksi ruokavaliota vaihtamalla. Eläintiloilla torjunnan tarve on yleensä erityisen suuri, koska siellä viljaa pidetään kotieläinten ulottuvilla. Sittenkin voisi väittää, että me kaikki olemme osallisia rottien tuhoamiseen; kuinkapa edes vegaani voisi selvittää, missä määrin jyrsijämyrkkyjä käytetään lähikaupassa tai julkisessa tilassa, jossa hän päivittäin liikkuu.

Yllättävää kyllä, Rentokilin harvat intersubjektiivisesti painottuneet rottatulkinnat ovat sävyltään hyvin myönteisiä. Rentokilin (n. d.) mukaan "mustarotat ovat hyviä kiipeilijöitä ja elävät onnellisina ullakoilla". Isorotat puolestaan kaivavat mieluummin kuin kiipeilevät. Rottien lempiruoaksi Rentokil (n. d.) nimeää viljatuotteet. Tulkinnoissa voi nähdä implisiittistä paheksuntaa siitä, että rotta käyttää hyväkseen tiloja ja ruokia, jotka eivät hänelle kuulu. Myönteisten tunteiden tulkitseminen on sinänsä tärkeää, mutta tässä yhteydessä herää kysymys, mitä myrkyttämämme rotta kokee.

Heurekan rottiin liitetään intersubjektiivisissa käännöksissä melko monipuolinen tunnekirjo: onnellisuutta, nautintoa, tyytyväisyyttä, rakkautta, hauskuutta, iloa, innostusta, onnistumista, turhautumista, tylsyyttä, hämmennystä, jännitystä, pelkoa, vihastumista, kipua (KPR 22.1.2011; KPR 23.9.2011; KPR 12.12.2011; KPR 21.12.2011; KPR 9.2.2012; KPR 29.3.2012; KPR 19.11.2012; KPR 25.11.2012; KPR 2.5.2013; KPR 6.11.2013; KPR 28.3.2016; KPR 4.11.2016; RKP 17.4.2017 ym.). John O'Neill (2006) esittää, että toislajisten puolestapuhujan legitimiteetti perustuu yhtäältä asiantuntemukseen, toisaalta huolenpitoon siitä, joka ei puhu. Myös Heurekan intersubjektiivisten tulkintojen uskottavuutta kasvattaa se, että ne pohjautuvat osittain tieteellisiin tutkimustuloksiin:

Mistä tunnistaa iloisen rotan? Yksi vastaus saattaa piiliä rotan korvissa tai oikeastaan niiden värisävyssä, kertoo viime vuoden loppupuolella julkaistu tutkimus. (RKP 8.5.2017) 
Tutkimukset osoittavat myös, että mielihyvää kokevat rotat sirkuttavat 50000 hertsin taajuudella, kun taas 22000 hertsin korkuiset äänet liittyvät rotilla kielteisiin tunteisiin (RKP 17.4.2017; RKP 8.5.2017). Rottien yksilöllisiä temperamenttieroja tulkitaan samankaltaisin sanakääntein kuin voisimme kielentää vaikkapa lasten oppimiseen vaikuttavia taipumuksia (KPR 24.2.2013 ym.). Heurekassa rottien tunne-elämän ymmärtäminen näyttää olevan myös asiakkaiden mielestä relevanttia: "Meiltä kysytään usein, miten kesyrottien hyvinvointi ja tarpeet otetaan huomioon Heurekassa." (RKP 7.12.2016.) Rentokililla sitä vastoin kysymys rottien kärsimyksestä ei kuulu usein kysyttyihin kysymyksiin.

\section{Riskistä korvaamattomaan apuun - rottien interaktantiaalinen tulkit- seminen}

Interaktantiaalisella kääntämisellä tarkoitan lähtötoimijan intressien semioottista prosessointia. Rentokilin (n. d.) käännöksissä rotat näyttäytyvät määrätietoisina toimijoina: "Rotat voivat olla erittäin sinnikkäitä ja jos ne onnistuvat pääsemään kotiisi tai yritykseesi, ne voivat levittää tauteja, aiheuttaa huomattavia vahinkoja ja saastuttaa ruokaa." Rotat vaurioittavat, nakertavat, repivät, aiheuttavat tulipaloja, kaivavat maata rakenteiden alta. Rottien vaikutus ympäristöönsä on totaalinen: rotat "nakertavat kaikkea" ja "virtsaavat kaikkialle". Rottien läsnäolossa on ainekset isoonkin katastrofiin; rotat voivat olla "suunnaton riski" ja "aiheuttaa paniikkia". (Rentokil n. d.) Torjuva kertakaikkisuus ei alkuunkaan vastaa Oyaman (2006) toiveita ympäristön osatekijöiden kokeellisesta, joustavasta, monivivahteisesta puhuttamisesta.

Heurekan tulkinnoissa rottien toimijuuteen sitä vastoin suhtaudutaan myönteisesti, ja mahdollisuutta omaehtoisiin valintoihin pidetään tärkeänä. Tämä koskee myös koripalloilua:

Koripallon pelaaminen, kuin myös harjoitteleminen, on rotille aina vapaaehtoista. Ne tulevat itse pelikentälle, jos ovat pelituulella. Rottia ei pakoteta pelaamaan, vaan ne voivat milloin tahansa poistua kentältä. Myös kesken esityksen. (RKP 7.12.2016)

Suurimpana erona Rentokilin ja Heurekan interaktantiaalisten tulkintojen välillä pidän vastavuoroisuuden kokemusta. Heurekassa ajatellaan, että rotan toiminta voi myötävaikuttaa yhteisen päämäärän saavuttamiseen: aikuiset rotat ovat toimineet "korvaamattomana apuna poikasten rohkaisemisessa" (KPR 1.9.2016). Rottien kouluttamisen ajatellaan opettavan "kouluttajallekin jotakin" (KPR 27.5.2012), ja emotionaalisesti vuorovaikutus on antoisaa molemmille osapuolille: 
Rotat nauttivat [...] hoitajan päällä ja hihoissa kiipeilyistä. Pienten karvaisten kavereiden kanssa seurustelu on myös hoitajista varsin mukavaa.

(KPR 9.2.2013)

Kokemus palkitsevasta yhdessäolosta luo perustaa monilajisen yhteisön muodostumiselle. Eläinkokeista ja -viihteestä siirrytään kohti tunnustettua osallisuutta, jonka Donaldson ja Kymlicka (2015) mieltävät kehityssuunnaksi suhteessamme domestikoituihin toislajisiin.

\section{Tilaisuuksista näkökulmaan - rottien intermondiaalinen tulkitseminen}

Intermondiaalisella kääntämisellä tarkoitan ympäristön tulkitsemista jonkun toisen, vaikkapa rotan, näkökulmasta. Rentokilin rottatulkit ymmärtävät hyvin, mitä tuholaiset haluavat elinympäristöltään. Rottia on vaikeaa estää "pääsemästä rakennukseen nauttimaan ruoasta ja lämmöstä"; nämä "hyödyntävät kaikkia sopivia tilaisuuksia päästä kotiisi etsiessään suojaa ja ruokaa" (Rentokil n. d.). Toisaalta käännöksissä tehdään selväksi, että ihminen ei voi jakaa elintilaansa kaikkien halukkaiden kanssa. Hallussamme on monenlaisia paikkoja, joista rotan kaltaiset eläimet on pidettävä poissa. Tuholaisilla "ei ole mitään asiaa toimipaikallesi", toimistossasi "ei ole tilaa tuholaisille", eikä supermarket tietenkään ole "paikka tuholaisille" (Rentokil n. d.). Kunnanvaltuuston jäseniin Rentokil vetoaa seuraavasti:

Tuholaiset ovat viimeinen asia, jonka haluat nähdä yleisillä alueilla ja kunnan rakennuksissa, ja kuitenkin nämä alueet ovat ihanteellisia tuholaisille, koska ne tarjoavat laajat pesimisalueet ja ravintoa.

Tässä vaikeassa elinympäristössä tarvitset tuholaistorjunta-ammattilaisia. Eli meitä! (Rentokil n. d.)

Heurekassa rottien ympäristösuhdetta tulkitaan varsin toisenlaisista lähtökohdista. Rotan maailma ei pelkisty ruoan ja lämmön funktionalismiksi, vaan käännöksissä pyritään kuvittelemaan, kuinka rotta näkee sinivihreän ja ultravioletin kirjavan maailmansa (RKP 20.10.2017). Myös objektien merkityksiin etsitään rottamaisia näkökulmia: viisiviikkoinen rotta voi olla ihmisten silmissä vauva mutta "rotan silmissä täysin lisääntymiskykyinen, vieraan lauman jäsen" (KPR 23.12.2012). Rotan seurassa ihmistulkki voi löytää uusia näkökulmia myös itseensä: turvallisesta hoitajasta tulee rotan kiipeilypuu, taskusta ja hihasta piilopaikkoja (KPR 13.3.2016; RKP 27.7.2017). Toisaalta rotan maailma sijoittuu vahvasti ihmisen suunnittelemiin puitteisiin. Vuorokausi ja vuodenajat tuntuvat 
Rottalassa vain epäsuorasti, ja vaihtelua rottien elämään tuovat hoitajien tarjoamat virikkeet. Tiedekeskuksen seinien sisälle pyritään rakentamaan mahdollisimman turvallista, viihtyisää ja mielenkiintoista rottamaailmaa.

\section{Lopuksi}

Edellä tarkasteltiin rottien kielellistä tulkitsemista esimerkkinä nisäkäslahkojen ja samalla toki myös lajien välisestä kääntämisestä. Rentokililla rottien merkkeihin kiinnitetään huomiota vain siksi, että rotat voitaisiin torjua mahdollisimman perusteellisesti. Torjuntayritysten elinehtona on ihmisten ja rajatapausten päättymätön konflikti, joka tulkinnoissa otetaan annettuna. Dehumanisoivat rottatulkinnat helpottavat päätöstä rottien tuhoamisesta ja estävät asianosaisia suistumasta lajienväliseen ystävyyteen antropologi Louis-Vincent Thomas'n (1993) tapaan. Heurekan rotat puolestaan lähestyvät monessa suhteessa Donaldsonin ja Kymlickan (2011) ajatusta toislajisista eläimistä kansalaisina. Rottien ja ihmisten muodostamassa yhteisössä jyrsijät pääsevät tekemään yhteistyötä ihmisten kanssa ja ammentamaan vaikutteita kädellisten kulttuurista. Kanssakäyminen on vastavuoroista, ja myös rottien voi katsoa hyötyvän siitä. Toisaalta siirtymä viemäristä tiedekeskukseen myös rajoittaa rottien liikkumavaraa. Rotat eivät ole tasavertaisia kansalaisia, vaan heidän yhteiskunnallinen asemansa rinnastuu esimerkiksi lapsen tai kehitysvammaisen tilanteeseen.

Rotista välittävä ihminen voi halutessaan välttää tukemasta taloudellisesti Heurekan rottakoulutusta, mutta ruoantuotantoon, liiketoimintaan ja kunnallispolitiikkaan kietoutuvista myrkytyksistä on vaikeaa sanoutua irti. Rottasuhteidemme ongelmiin ei ole olemassa veganismin kaltaista helppoa ratkaisua, mutta lahkojen väliset kääntäjät voivat osaltaan pyrkiä konfliktin transformaatioon ja representationaalisen oikeudenmukaisuuden tavoitteluun (ks. Calzada Pérez 2007; Yameng 2007). Käsitykset rottien suomalaisille aiheuttamasta uhasta ovat osittain liioiteltuja, ja usein vahinkoja on mahdollista ehkäistä ennalta, kunhan rottien tappaminen antikoagulanteilla tunnustetaan eläinpoliittiseksi ongelmaksi. Vaikka rotat ovat toislahkoisia eläimiä, nisäkkäinä he ovat myös luokkatovereitamme, jotka kokevat iloa, surua ja pelkoa siinä missä ihmisetkin (Telkänranta 2015). Nisäkkäiden luokassa rotat vieläpä ovat läheisempää sukua kädellisille kuin koira tai hevonen. Osaamme tulkita rottien endosemioottisia koodeja, ja ymmärrämme jossain määrin heidän tunteitaan, tavoitteitaan ja näkökulmiaan. Tältä pohjalta voisimme opetella ottamaan huomioon rotan kuin rotan - koripallotähdestä tuholaiseen, joka tekee kuolemaa ultraäänien kirjomassa hiljaisuudessa. 


\section{KIITOKSET}

Artikkelin syntyyn vaikutti merkittävästi kaksi henkilöä: Lotta Luhtala, joka kutsui minut luennoimaan lajienvälisestä näkökulmasta kääntämiseen 5.4.2019, sekä artikkelin alussa siteerattu kääntäjä, jonka sanoihin kiteytyi opiskeluaikoina kokemani huoli. Vaikka kolmen sanan kirjoittamisesta oli kulunut lähemmäs kaksikymmentä vuotta, kääntäjä tunnisti välittömästi itsensä ja suostui lainaukseen. Kiitos myös käsikirjoitukseen perehtyneille henkilöille.

\section{KIRJALLISUUS}

Arluke, Arnold ja Clinton R. Sanders. 1996. Regarding animals. Philadelphia: Temple University Press.

Bachmann-Medick, Doris. 2009. "Introduction. The translational turn." Translation Studies 2 (1): 2-16.

Benjamin, Walter. 1977 [1916]. "Über Sprache überhaupt und über die Sprache des Menschen." Gesammelte Schriften II.1, 140-157. Frankfurt am Main: Suhrkamp Verlag.

Berman, Antoine. 1984. L'épreuve de l'étranger. Culture et traduction dans l'Allemagne romantique. Paris: Gallimard.

Bourjea, Michelle. 1986. "Agua viva. Au fil des mots. Analyse critique de la traduction en français de Agua viva de Clarice Lispector." META. Journal des traducteurs 31 (3): 258-271.

Brier, Søren. 2010. "Autopoiesis." The Routledge Companion to Semiotics, toim. Paul Cobley, 171. London: Routledge.

Calzada Pérez, Maria. 2007. "Translating conflict. Advertising in a globalised era." Translating and interpreting conflict, toim. Myriam Salama-Carr, 149-165. Amsterdam: Rodopi.

Campbell, Neil, Jane Reece, Lisa Urry, Michael Cain, Steven Wasserman, Peter Minorsky ja Robert Jackson. 2008. Biology. 8th edition. San Francisco: Pearson Benjamin Cummings.

Chakrabarty, Dipesh. 2009. "The climate of history. Four theses." Critical Inquiry 35 (2): 197-222.

Chesterman, Andrew. 2001. "Proposal for a Hieronymic oath." The Translator 7 (2): 139-154.

Cronin, Michael. 2017. Eco-translation. Translation and ecology in the age of the anthropocene. London: Routledge. 
Deckha, Maneesha. 2008. "Intersectionality and posthumanist vision of equality." Wisconsin Women's Law Journal 23 (2): 249-268.

Deely, John. 2001. "Physiosemiosis in the semiotic spiral. A play of musement." Sign Systems Studies 29 (1): 27-48.

Derrida, Jacques. 1990 [1985]. "Théologie de la traduction." Du droit à la philosophie, 371-394. Paris: Galilée.

Donaldson, Sue ja Will Kymlicka. 2011. Zoopolis. A political theory of animal rights. Oxford: Oxford University Press.

Donaldson, Sue \& Will Kymlicka. 2015. "Farmed animal sanctuaries: the heart of the movement? A socio-political perspective." Politics and Animals 1 (1): 50-74.

Douglas, Mary. 2000 [1996]. Puhtaus ja vaara. Ritualistisen rajanvedon analyysi. Tampere: Vastapaino.

Dupré, John. 2002. Humans and other animals. Oxford: Clarendon Press.

Fromm, Harold. 1996 [1978]. "From transcendence to obsolescence. A route map." The ecocriticism reader. Landmarks in literary ecology, toim. Cheryll Glotfelty \& Harold Fromm, 30-39. Athens: The University of Georgia Press.

Heureka. n. d. "Rottakoripallo Heurekassa." Luettu 19.3.2019. https://www.heureka. fi/event/rottakoripallo/.

Jackson, Jean. 2003. "Translating the pain experience." Translation and ethnography. The anthropological challenge of intercultural understanding, toim. Tullio Maranhão ja Bernhard Streck, 172-194. Tucson: University of Arizona Press.

Jakobson, Roman. 1960. "Closing statement. Linguistics and poetics." Style in language, toim. Thomas A. Sebeok, 350-377. Cambridge, Massachusetts: The M. I. T. Press.

Kahn, Mary. 2001 [1992]. "The passive voice of science. Language abuse in the wildlife profession." The ecolinguistics reader. Language, ecology and environment, toim. Alwin Fill ja Peter Mühlhäusler, 241-244. London: Continuum.

Kohn, Eduardo. 2013. How forests think. Toward an anthropology beyond the human. Berkeley: University of California Press.

Koivisto, Elina, Pertti Koivisto, Ilpo K. Hanski, Tapio Korkolainen, Timo Vuorisalo, Ari Karhilahti, Ville Välttilä, lida Loivamaa ja Sanna Koivisto. 2016. Prevalence of anticoagulant rodenticides in non-target predators and scavengers in Finland. Helsinki: Tukes.

Koripallorotat. 2010-2016. "Rottakoripallo." Luettu 19.3.2019. http://koripallorotat. blogspot.com/.

Kull, Kalevi. 2010. "Umwelt and modelling." The Routledge Companion to Semiotics, toim. Paul Cobley, 43-56. London: Routledge. 
Kull, Kalevi ja Peeter Torop. 2003. "Biotranslation. Translation between Umwelten." Translation translation, toim. Susan Petrilli, 315-328. New York: Rodopi.

Kurtto, Marianna. 2015. Rottakuningas. Helsinki: WSOY.

Lefevere, André. 1977. Translating literature. The German tradition from Luther to Rosenzweig. Assen: Van Gorcum.

Lefevere, André. 2004 [1982]. "Mother Courage's cucumbers. Text, system and refraction in a theory of literature." The translation studies reader, 2nd edition, toim. Lawrence Venuti, 239-255. New York: Routledge.

Malamud, Randy. 2007. "Famous animals in modern culture." A cultural history of animals in the modern age, toim. Randy Malamud, 1-26. Oxford: Berg.

O'Neill, John. 2006. "Who speaks for nature?" How nature speaks. The dynamics of the human ecological condition, toim. Yrjö Haila ja Chuck Dyke, 261-278. Durham: Duke University Press.

Oyama, Susan. 2006. "Speaking of nature." How nature speaks. The dynamics of the human ecological condition, toim. Yrjö Haila ja Chuck Dyke, 49-65. Durham: Duke University Press.

Rentokil. n. d. "Rentokil." Luettu 24.3.2019. https://www.rentokil.fi/.

Rottakoripallo. 2016-2018. "Heurekan koripallorotat." Luettu 19.3.2019. https://rottakoripallo.wordpress.com/.

Sebeok, Thomas A. 1991. A sign is just a sign. Bloomington: Indiana University Press.

Sebeok, Thomas. 2001. Global semiotics. Bloomington: Indiana University Press.

Segal, Alan F. 2003. "Text translation as a prelude for soul translation." Translating cultures. Perspectives on translation and anthropology, toim. Paula G. Rubel ja Abraham Rosman, 213-247. Oxford: Berg.

Serpell, James. 1996 [1986]. In the company of animals. A study of human-animal relationships. Cambridge: Cambridge University Press.

Steiner, George. 1975. After Babel. Aspects of language and translation. London: Oxford University Press.

Telkänranta, Helena. 2015. Millaista on olla eläin? Helsinki: Suomalaisen Kirjallisuuden Seura.

Thiong'o wa, Ngũgi. 2009. "Translated by the author. My life in between languages." Translation Studies 2 (1): 17-20.

Thomas, Louis-Vincent. 1993. Mélanges thanatiques. Paris: L'Harmattan.

Tukes. n. d. "Biosidirekisteri." Luettu 31.5.2019. http://biosidit.tukes.fi/kemikaaliprosessit/biweb.nsf/search.htm. 
Verschueren, Jef. 2007. "The interventionist role of (re)contextualization in translation." Translation as intervention, toim. Jeremy Munday, 71-83. London: Continuum.

Vihelmaa, Ella. 2009. "L'éthique du traducteur à l'épreuve de l'écologie." META. Journal des traducteurs / Translators' Journal 54 (4): 857-870.

Vihelmaa, Ella. 2018. Kielen kääntöpuolella. Kuinka tutkia toislajisten merkkien kääntymistä ihmiskielelle? UEF Electronic Publications. http://urn.fi/urn:nbn:fi:uef-20190920.

Watt, Barbara., Alex Proudfoot, Sally Bradberry ja J. Allister Vale. 2005. "Anticoagulant rodenticides." Toxicological Reviews 24 (4): 259-269.

Webster, J. P., P. H. Lamberton, C. A. Donnelly ja E. F. Torrey. 2006. "Parasites as causative agents of human affective disorders?" Proceedings of the Royal Society B 273 (1589): 1023-1030.

West, Russell. 2002. "Teaching nomadism. Inter/Cultural Studies in the context of Translation Studies." Cultural studies, interdisciplinarity and translation, toim. Stefan Herbrechter, 161-176. Amsterdam: Rodopi.

Willamo, Risto. 2005. Kokonaisvaltainen lähestymistapa ympäristönsuojelutieteessä. Sisällön moniulotteisuus ympäristönsuojelijan haasteena. Helsinki: Helsingin yliopisto, Biotieteellinen tiedekunta, Bio- ja ympäristötieteiden laitos.

Yameng, Liu. 2007. "Towards 'representational justice' in translation practice." Translation as intervention, toim. Jeremy Munday, 54-70. London: Continuum. 